\title{
Measuring Socio-Demographic Differences in Volunteers with a Value-Based Index: Illustration in a Mega Event
}

\section{Teresa Fayos Gardó, Martina G. Gallarza Granizo, Francisco Arteaga Moreno \& Elena Floristán Imizcoz}

VOLUNTAS: International Journal of Voluntary and Nonprofit Organizations

Official journal of the International Society for Third-Sector Research

ISSN 0957-8765

Voluntas

DOI 10.1007/s11266-013-9393-2

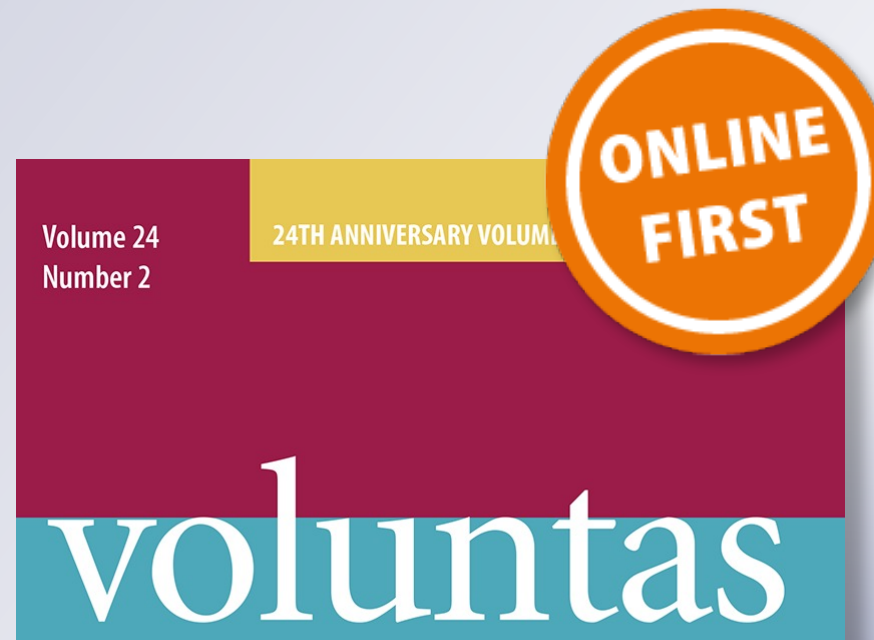

International Journal of Voluntary and Nonprofit Organizations
Springer

$11266 \cdot$ ISSN 0957-8765

24(2) 293-536 (2013)
Available ty online

黛 Springer 
Your article is protected by copyright and all rights are held exclusively by International Society for Third-Sector Research and The Johns Hopkins University. This e-offprint is for personal use only and shall not be selfarchived in electronic repositories. If you wish to self-archive your article, please use the accepted manuscript version for posting on your own website. You may further deposit the accepted manuscript version in any repository, provided it is only made publicly available 12 months after official publication or later and provided acknowledgement is given to the original source of publication and a link is inserted to the published article on Springer's website. The link must be accompanied by the following text: "The final publication is available at link.springer.com". 


\title{
Measuring Socio-Demographic Differences in Volunteers with a Value-Based Index: Illustration in a Mega Event
}

\author{
Teresa Fayos Gardó • Martina G. Gallarza Granizo • \\ Francisco Arteaga Moreno • Elena Floristán Imizcoz
}

(C) International Society for Third-Sector Research and The Johns Hopkins University 2013

\begin{abstract}
The phenomenon of volunteering can be analysed as a consumer experience through the concept of value as a trade-off between benefits and costs. In event volunteering, both the expected value (pre-experienced) and the perceived value (post-experienced) of volunteering can be assessed. With this purpose, an online quantitative survey is conducted with a sample of 711 volunteers in a religious mega event, with questions related to five dimensions of their experience: efficiency, social value, play, spirituality and time spent. These five scales, properly tested are used for building a multidimensional index of both the expected and perceived value of the volunteer experience. ANOVAs test show significant differences on the index in both moments upon the socio-demographic profiles: negative expectations/experience balance by age, contrasted results by sex, and more experienced volunteers being more critical with the value experienced. Implications for event managers are proposed, in line with the motivation of volunteers.
\end{abstract}

Keywords Volunteering · Mega events · Value dimensionality · Consumer experience

\footnotetext{
T. Fayos Gardó $(\bowtie) \cdot$ M. G. Gallarza Granizo Universitat de València, Valencia, Spain

e-mail: teresa.fayos@uv.es

M. G. Gallarza Granizo

e-mail: martina.gallarza@uv.es

\section{F. Arteaga Moreno · E. Floristán Imizcoz}

Facultad de Estudios de la Empresa, Universidad Católica de Valencia

"San Vicente Mártir", Valencia, Spain

e-mail: francisco.arteaga@ucv.es

E. Floristán Imizcoz

e-mail: elena.floristan@ucv.es
}

Departamento de Investigación y Comercialización de Mercados, Facultad de Economía, 
Résumé Le phénomène du bénévolat peut être analysé en tant qu'expérience de consommateur au travers du concept de valeur, entendu comme compromis entre un coût et un bénéfice. En ce qui concerne le bénévolat événementiel, il est possible d'estimer la valeur attendue (à priori) et la valeur ressentie (à postériori). Dans cette optique, une étude quantitative a été menée en ligne sur un échantillon de 711 bénévoles pour un événement religieux de grande ampleur, avec des questions concernant cinq aspects de leur expérience : efficacité, valeur sociale, amusement, spiritualité et temps consacré. Ces cinq échelles dument testées sont ici utilisées pour établir un indicateur pluridimensionnel de la valeur attendue et ressentie pour cette expérience bénévole. L'analyse de la variance met en évidence des différences significatives d'indicateur pour ces deux valeurs en fonction des profils sociodémographiques : bilan attentes/expérience négatif avec l'âge, résultats contrastés selon le sexe, et bénévoles expérimentés davantage critiques quant à la valeur ressentie. En conséquence, des propositions sont ici émises à l'attention des organisateurs d'événements pour mieux motiver les bénévoles.

Zusammenfassung Das Phänomen der ehrenamtlichen Tätigkeit lässt sich als eine Verbrauchererfahrung mittels des Wertkonzepts als ein Kompromiss zwischen Kosten und Nutzen analysieren. Bei ehrenamtlichen Tätigkeiten im Rahmen von Veranstaltungen können sowohl der erwartete Wert (vor gesammelter Erfahrung) als auch der wahrgenommene Wert (nach gesammelter Erfahrung) der ehrenamtlichen Tätigkeit bestimmt werden. Zu diesem Zweck wird eine quantitative OnlineBefragung von 711 ehrenamtlich Tätigen bei einer religiösen Großveranstaltung durchgeführt, die Fragen zu fünf Erfahrungsbereichen enthält: Effizienz, sozialer Wert, Freizeit, Spiritualität und Zeitaufwand. Diese angemessen getesteten fünf Größen werden verwandt, um einen multidimensionalen Index für den erwarteten und wahrgenommenen Wert in Verbindung mit der ehrenamtlichen Tätigkeit zu erstellen. Die Varianzanalyse (Analysis of Variance, ANOVA) zeigt bedeutende Unterschiede auf dem Index zwischen beiden auf die sozio-demographischen Profile wirkenden Momente: das Gleichgewicht negativer Erwartungen/Erfahrungen je nach Alter, gegensätzige Ergebnisse je nach Geschlecht und ehrenamtlich Tätige mit größerer Erfahrung, die den erlebten Wert kritischer betrachten. Im Einklang mit der Motivation eherenamtlich Tätiger werden Implikationen für Veranstaltungsmanager aufgestellt.

Resumen El fenómenos del voluntariado puede ser analizado como una experiencia de consumidor mediante el concepto de valor como una solución de compromiso entre beneficios y costes. En el voluntariado de eventos, se puede evaluar tanto el valor esperado (pre-experimentado) como el valor percibido (post-experimentado) del voluntariado. Con este fin, se realiza una encuesta cuantitativa online con una muestra de 711 voluntarios en un mega-evento religioso, con preguntas relacionadas con cinco dimensiones de su experiencia: eficiencia, valor social, desempeño, espiritualidad y tiempo dedicado. Estas cinco escalas, adecuadamente probadas se utilizan para crear un índice multidimensional tanto del valor esperado como del valor percibido de la experiencia del voluntario. La prueba ANOVA 
muestra diferencias significativas en el índice en ambos momentos con respecto a los perfile socio-demográficos: expectativas negativas/experiencia base por edad, resultados contrastados por sexo, y voluntarios más experimentados que son más críticos con el valor experimentado. Se proponen implicaciones para los gestores de eventos, en línea con la motivación de los voluntarios.

\section{Introduction}

Volunteering is an activity that has become remarkably widespread in Western societies, even though there are still major differences between countries in terms of its social penetration (percentage of people involved in volunteer work) and strength and intensity (measurement of engagement by number of hours done or an equivalent measure) (GHK Consulting 2010; Handy et al. 2000; Holmes et al. 2010).

It is acknowledged by secondary data that in all Europe in general, and in Spain in a more precise way (Beerly et al. 2004) the number of individuals involved in volunteering has significantly increased in the last 10 years, due to a combination of sociological, political and economic factors (GHK Consulting 2010). However, the sharp differences between Western countries (Charities Aid Foundation 2011) explicitly show how difficult it is to measure and evaluate volunteering, because the idiosyncrasy of the activity is highly heterogeneous (Gallarza 2000; McCurley and Vesuvio 1985; García-Mainar and Marcuello 2007; García et al. 2011).

In order to make better use of this business and social force and achieve a more complete understanding of it, this paper aims to analyse volunteering as a consumer phenomenon through the value concept, in order to provide a more original and thought-provoking viewpoint. Value is considered by many to be the cornerstone of the study of consumer behaviour (Holbrook 1999; Jensen 1996; Woodruff 1997); it is commonly understood as a trade-off between benefits and costs that the consumer makes when taking decision of consumption (Zeithaml 1988; Lovelock 1996; Monroe 2003; Zeithaml and Bitner 1996). Devoting time and effort to a voluntary activity is a personal choice in the use of our resources in the leisure market and can, therefore, be viewed as a kind of consumption, where the consumer (the volunteer) derived positive values, whereas he/she is involved in sacrifices of time and effort.

The empirical literature on volunteering has focused mainly on motivation as a pre-assessment of the act of volunteering (e.g. Callow 2004; Monga 2006; Farrell et al. 1998; Strigas and Newton-Jackson 2003; Saleh and Wood 1998; Hibbert Piacentini and Al Dajani 2003; Handy et al. 2006) and to a much lesser extent on post-assessments such as perceived quality of service or satisfaction (e.g. Elstad 1996; Vaughan and Shiu 2001). The value-based approach that we proposed in this study goes further than other previous knowledge on motives or experiences of volunteers because value helps to explain facets of consumer behaviour that occur before and after consumption (Gallarza et al. 2011). Our approach is original in the sense that it covers expectations (expected value) and experiences (perceived value) of volunteering. 
The setting chosen for testing this approach is the volunteering in cultural mega events. One of the most recent and comprehensive examples of volunteering as human capital has been the involvement of volunteers at tourism mega events. These are increasingly complex and spectacular expressions of the organisation and management potential of cities, countries and governments at all levels (Ritchie 1984; Elstad 1996; Fayos-Solá 1997), while from the individual's standpoint they are also opportunities to express civic pride and a willingness to take part actively or passively, which are a collective personality trait of contemporary societies (Kemp 2002; Gursoy and Kendall 2006; García-Mainar and Marcuello 2007).

This paper has a main objective to add to knowledge about mega event volunteering through first, a conceptual framework on the richness of the phenomenon of volunteering for Western societies where event volunteering is an emerging trend, and second, through the findings of a research carried out with a database of 711 volunteers who took part in a religious mega event in Spain. The activity of volunteering is viewed, in our approach, as a consumer experience that may be analysed using a variable that is ubiquitous in the study of marketing: perceived value. In this case, by building a composite index based on the different dimensions of value of the volunteer experience we can use its conceptual richness to learn about the effect this experience has on the individuals by examining the differences in the volunteers' self-assessment before and after the event.

Under the aforementioned main objective, the sub-objectives of the empirical study of this paper are threefold. First, to build an index for objectively measuring the value of the experience from the volunteers' perspective, i.e. measure their self-assessment as volunteers. Second, to use the index to evaluate the volunteers' experience at a mega event at two different points in time: before and after the holding of the event. Third, to examine whether there are significant differences in the average index value based on socio-demographic factors: age, sex and previous experience as a volunteer.

The paper is organised in five sections. The conceptual framework covers three headings: the review of value within consumer literature, the review of the volunteer's role in the events, and the characteristics and conceptualisation of volunteering (both normative and descriptive approaches), where the review of the relevance of socio-demographic variables is depicted. The third section presents the methodology (the instrument, the sample and the setting). The fourth section covers analysis and finding: scales reliability and validity, how the proposed index was built, the measurement of significant differences, and the ranking of the index on age, sex and experience. In the fifth section conclusions, discussion and managerial implications are proposed, as well as limitations and further research to be done.

\section{Conceptual Framework}

Value as a Cornerstone of Consumer Behaviour and a New Perspective for Researching Volunteering

As aforementioned, to achieve the triple objective presented in the introduction, we chose to use value as one of the key aspects as it allows consumption to be 
examined both before and after the decision, in other words as expected value and perceived value (Gallarza et al. 2011). Indeed, several authors argue that value can be understood at two stages of the consumer experience and use a number of names to make this distinction; expected value and received value (Kotler et al. 2009, or pre-use value and post-use value (Lovelock 1996).

The approach we have chosen for explaining volunteering is the value conceptualisation as trade-off between benefits and costs. This approach has its origins in the early proposal made by Zeithaml (1988, p. 14) ('perceived value is the consumer's overall assessment of the utility of a product, based on the perceptions of what is received and was is given'), which has stood as one of the most universally accepted definitions of customer value. It has influenced a stream of literature based on the 'get-versus-give' trade-off (e.g. Lovelock 1996; Monroe 2003; Zeithaml and Bitner 1996).

A second key aspect of the notion of value is its universally acknowledged multidimensional nature (Heskett et al. 1997; Sheth et al. 1991; Kotler et al. 2009; Nilson 1992; Holbrook 1999; Gallarza and Gil 2006, 2008).

From among the extensive conceptual research into multidimensionality of value, Holbrook's contribution has been signalled as paradigmatic (Smith 1999): this researcher was a pioneer in exploring the hedonic dimension of consumer value (Holbrook and Hirschman 1982; Holbrook and Corfman 1985) and he has further provided the most comprehensive and rich typology of values (Holbrook 1999). According to the setting and scope of our research, this Holbrook's typology has been praised because it 'allows an easier adaptation to a broader range of consumption experiences, such as religion, the arts and leisure activities' (Day and Crask 2000), making it very attractive for the type of experience we are examining here: being a volunteer at a religious event.

The conceptualisation proposed by Holbrook (1999, p. 5) pursues a philosophical approach that encompasses a comprehensive typology of consumer value (Holbrook 1999, p. 5). This typology is based on a three-dimensional paradigm: extrinsic versus intrinsic value; self-oriented versus other-oriented value; and active versus reactive value. When combined, these three distinctions create a typology that defines eight inter-related primary categories of consumer value (according to the resulting $2 \times 2 \times 2$ cross-classification (Table 1)—namely, efficiency (e.g. convenience); excellence (e.g. quality); status (e.g. success); esteem (e.g. materialism); play (e.g. fun); aesthetics (e.g. beauty); ethics (e.g. justice, virtue) and spirituality (e.g. faith).

Table 1 Holbrook's typology of consumer value (Holbrook 1999)

\begin{tabular}{llll}
\hline & & Extrinsic & Intrinsic \\
\hline Self oriented & Active & Efficiency (convenience) & Play (play) \\
& Reactive & Excellence (quality) & Aesthetics (beauty) \\
Other oriented & Active & Status (success) & Ethics (virtue, justice) \\
& Reactive & Esteem (reputation, materialism) & Spirituality (faith) \\
\hline
\end{tabular}


Holbrook's value structure is considered the most appropriate for research into a volunteering experience as it includes the functional, social, hedonic and altruistic facets of human behaviour, all of them being interesting for approaching volunteering.

Four variables out of its eight values were considered to be more interesting for researching volunteering. We give rationale of this choice, based on the idiosyncrasy of the experience researched: volunteering in a religious event. Within self-oriented values, as active variables, efficiency and play were retained, since volunteering is an active rather than a reactive experience. So, first, in the functional dimension the active variable (efficiency) was chosen as opposed to the reactive one (quality as excellence). Perception of efficiency is viewed as a measure of utility related to the tasks given to volunteers. This dimension is important in relation with the literature on the dissatisfaction of volunteers in events that usually complain of being underrated in their capacities (Kemp 2002; Cuskelly et al. 2004).

Second, in the hedonic dimension, that is to say enjoyment (extrinsic and personal in Holbrook's typology), play or fun dimension is considered rather than aesthetic, as we believe it is important to cover the recreational and personal enjoyment aspects entailed by an activity that is by definition voluntary.

Third, an overall social dimension was considered, involving both esteem and status, as we looked at social interactions as a specific feature of consumption value (Sheth et al. 1991). Volunteering has a lot to do with social interaction; previous research into the motivation of festival volunteers used a scale comparing 'otherserving' with 'self-serving' (Handy et al. 2006).

Forth, in the altruistic (i.e. other-oriented) dimension, according to the setting chosen, spirituality was used to analyse involvement in a religious event.

Except for spirituality, which is very context specific, this four-dimensional structure is consistent with previous research into the experience of volunteering at special events (e.g. Strigas and Newton-Jackson 2003; Farrell et al. 1998; Handy et al. 2006).

Finally, following conceptualisations of value as a trade-off, i.e. as a balance between sacrifices and costs (Zeithaml 1988), the cost of the effort and time incurred was introduced. This is because it is a typical sacrifice or cost in the literature about value (Berry and Yadav 1997) and is relevant to the experience being examined as the opportunity cost of devoting time to volunteer service rather than to any other activity. Hence time is seen as the only price paid to consume volunteerism. These five dimensions (four positive and five negative) provide knowledge of separate facets of the volunteering experience.

\section{Volunteering in Events as a Particular Facet of Voluntary Action}

Organising social or cultural events and volunteering are closely linked since, as Goeldner et al. (2000, p. 235) point out, 'as the number of events has grown and expanded in size and complexity, the number of staff and volunteers has mushroomed'. Moreover, in some cases 'without the personal investment of the volunteers, these mega events like the Olympics could simply not have been arranged' (Kemp 2002, p. 110). At a management level, organisers of large or small 
events are aware of the importance of this human capital. However, there has been little academic interest in this particular stakeholder in the abundant literature about event tourism.

While there are numerous studies about the perceptions of other groups involved in organising events such as residents (e.g. Ritchie and Aitken 1984; Waitt 2003; Kim et al. 2006; Gursoy and Kendall 2006) and tourists (e.g. Crompton and McKay 1997; Kim and Morrison 2005; Lee et al. 2006; Shonk and Chelladurai 2008), the experience of volunteering at tourism events is academically understudied in spite of its management potential, even being described as the 'the hidden workforce' (Kemp 2002).

Research to date into the commercial management of tourism events is extensive but relatively heterogeneous. After early development (e.g. Ritchie 1984; Ritchie and Aitken 1984), and although it has occasionally only been addressed erratically (Fayos-Solá 1997), it is now an important area of study in destination marketing. Academic tourism literature acknowledges that organising mega events can be crucial for the marketing and strategic development of destinations (Lee and Taylor 2005). The usual promotion of destinations can sometimes be significantly enhanced by hosting an event (Monga 2006).

The most conceptually comprehensive definition and categorisation of a mega event was given by Donald Getz at a conference of the Swedish Institute for Regional Research in 1997 (Getz 1997): 'planned occurrences of limited duration which have an extraordinary impact on the host area' (Fayos-Solá 1997, p. 242). Mega events are, therefore, broadly conceptualised in many different typologies; the most common refer to size (measured by the number of participants with the biggest being mega events) or purpose, with a distinction being made here between volunteering at sports events (Olympics), at cultural events (festivals) and finally at religious events (pilgrimages and other meetings). The latter is probably the least common and, therefore, the one in which there is still a wider field of research.

\section{A Normative Approach to Volunteering: Trying to Define What Volunteering is}

Since the 70s, academics have been interested in multiple disciplinary approaches by voluntary activity and its boundaries (e.g. Weisbrod 1975; McCurley and Vesuvio 1985; Cnaan et al. 1996; Handy et al. 2000; Holmes et al. 2010), however, there is still no consensus on its conceptualisation. This activity, difficult to delimitate and complex to measure, is part of the non-profit sector (Beerly et al. 2004), as opposed to the private and the public sector. However, most modern manifestations of volunteerism are not confined solely to the non-profit sector (e.g. volunteering at events), but are consistent in that volunteerism stems from a positive personal attitude that meant that there is a higher life satisfaction in helping others or society (Gallarza 2000), resulting in greater personal and social welfare (Mellor et al. 2009).

The institutional perspective is neither unique: volunteering has been defined, in a non-matching way, by different agencies until consensually defined by the European Commission (GHK Consulting 2010): 'Volunteering is defined as all forms of voluntary activity, whether formal or informal. Volunteers act under their 
own free will, according to their own choices and motivations and do not seek financial gain. (...) Volunteering is a journey of solidarity and a way for individuals and associations to identify and address human, social or environmental needs and concerns. Volunteering is often carried out in support of a non-profit organisation or community-based initiative (...)'.

Despite this attempt at consensus (FOLIA 2011), some other sources point out that there is no common definition of what is and what is not a volunteer (Plataforma de Promoción de Voluntariado de España 2011). For example, in some countries voluntary actions blend into forms of paid work, as there are volunteers who are token given, while other authors (e.g. FOLIA 2011) consider that episodic volunteering such as event volunteering is not pure volunteering. As a consequence of these fuzzy conceptual limits, in the UE-2, difficulties in collecting information on this activity are identified (GHK Consulting 2010): 'the discrepancies between different national surveys, studies and methods means that it has not been possible to provide a statistically accurate comparison across Europe'.

As the normative perspective remains unclear, we adopt now a descriptive perspective, where volunteering is seen as a very contrasted activity, where previous research shows the relevance of socio-demographic variables in the explanation of the phenomenon.

\section{A Descriptive Approach to Volunteering as a Contrasted Activity}

According to 2011 data from the Charity Aid Foundation, an overview of the international situation of volunteering as a social phenomenon in the early $21 \mathrm{st}$ century can be depicted through the World Giving Index, which is based on three variables (donating money to an organisation, volunteering time to an organisation and what is called helping a stranger) and covers a total of 153 countries.

According to this Index, USA and Ireland are, jointly, the most 'giving' countries in the world. In terms of the importance of volunteering, $43 \%$ of respondents in USA were doing voluntary work in the month prior to interview and $39 \%$ in New Zealand. The lowest index ratings are for southern European countries such as Spain (index rating 83), Portugal (127) and Greece (151). Although Spain's index rating is similar to France's, its composition is very different because France's volunteerism percentage is almost double Spain's (27\% vs. $18 \%$ ).

However, as mentioned above, there may be cultural issues behind these figures. Volunteering in Spain has traditionally been related to social services in areas that were unattended by government (García-Mainar and Marcuello 2007) where people engage on their own initiative as an amateur service thus reducing the need for many types of structured social services. Activities such as assisting family members or friends and neighbours will never be considered volunteering in Spain, while the same activity might come under structured social services in the USA or UK.

Reflecting these differences, today, there are many actual manifestations of the phenomenon of volunteering, and very different activities have been added to the concept building and supplementing it (Handy et al. 2000). Currently, voluntary actions satisfy varied interests, reaching more complex and interactive spaces with 
other agents (García et al. 2011), resulting in a heterogeneous sector. Volunteering is a complex reality in which different institutions come into play (such as business or public administration) creating new forms of volunteering that require recognition and reflection (Garrido 2011).

Among these new forms of volunteering, the dimension of time framework, proposed in works by Handy et al. (2006), Smith et al. (2010) and Holmes et al. (2010) for explaining different voluntary actions offers meaningful insights for understanding event volunteering, in terms of time commitment and seasonality.

On one hand, although time commitment is relevant for describing volunteering, no general agreement as to the commitment of time exists to be considered volunteer. Regarding this question, Ruiz Olabuénaga (2001) distinguishes between volunteers in a large $(1 \mathrm{~h} /$ month minimum) or strict sense (over $16 \mathrm{~h} / \mathrm{month}$ ), while Handy et al. (2006) distinguish between sporadic and long-term volunteer. In the same line, Holmes et al. (2010, p. 265) differentiate between regular volunteer and episodic volunteers, identifying the latter to those who just want to help with short, well-defined tasks. Specific differences in episodic volunteering behaviour were found in terms of age, place of birth and residence (Handy et al. 2006).

On the other hand, seasonality in volunteering is another issue about which little information exists (FOLIA 2011). The average time of dedication to social action volunteering in Spain is around $10 \mathrm{~h} / \mathrm{week}$, while almost a third of the volunteers have not a continuous dedication. Moreover, NGOs promote solidarity stays in summer since increasingly the 'free' time and different lifestyles require organisations to favour a more flexible volunteer time management. Also inconclusive is the data on dwell time in volunteer organisations (FOLIA 2011) although Dávila et al. (2005) conclude that the average stay is around year and half.

As a further and final step in our descriptive approach to volunteering, the literature also proposes explaining volunteering through socio-demographic variables such as age (e.g. Callow 2004; Handy et al. 2006; Dávila and Chacón 2004), place of residence (e.g. Handy et al. 2006), religion (e.g. Tao and Yeoh 2007; García-Mainar and Marcuello 2007) and continuance commitment (e.g. Elstad 2003), as well as other more complex topics such as self-congruity (e.g. Beerly et al. 2004) and personal wellbeing (e.g. Mellor et al. 2009). Furthermore, Wilson (2000) performs a thorough review of previous research finding additional variables as education, sex, race, marital or parental status, income, jobs, and social networks, although he considers that more research is needed, especially for younger groups. Interest in socio-demographic variables is, therefore, inbuilt in the study of volunteerism as it is a personal and social phenomenon.

What does seem obvious in a sociological approach to volunteering is the wealth and complexity of this social phenomenon, since cultural differences are observed, along with significant difficulty in measuring it uniformly. These issues can be viewed as inducements to study it and gain greater insight into differences in profiles (by nationality or demographic variables) for both academic approaches and also from various disciplinary and professional viewpoints.

Bearing in mind all these earlier works and in order to enhance our understanding of volunteer behaviour in the particular case of tourism events, this paper adopts a value-based approach, that is somewhat unusual in this type of studies. In the 
following section we present the methodology that has allowed us to empirically connect the two conceptual topics chosen for this paper (events and volunteering), analysed through the lens of a third one (value) as a mean of providing a better understanding of the experience of being a volunteer in a special event.

\section{Methodology}

\section{Measurement Instrument}

The methodology undertaken for building the questionnaire for assessing pre and post value perceptions was divided into two stages. First, according to the need of applying qualitative techniques when no previous scaling effort is found, qualitative information was collected from two sources: (a) Four in-depth interviews with managers among the 5th Families World Meeting Organization and (b) Four focus groups with different profiles of volunteers (students from Valencia, mid-age working women, over 50 year-old housewives, etc...). The structure proposed of five dimensions of value was consistent with the statements heard during focus group with volunteers.

Second, this information was supplemented by an additional review of the literature about research into volunteering in a number of areas. Particularly interesting was the paper by Monga (2006), which offers an insight into the motivation of volunteers at special events. The information was completed by a review of marketing literature about value concept and dimensions (e.g. Holbrook 1999; Sheth et al. 1991; Sweeney and Soutar 2001; Zeithaml 1988), where the tradeoff approach was considered (Zeithaml 1988) and Holbrook (1999)'s dimensionality was selected as a framework. The five scales that supported the five dimensions of value (fourth positive and one negative) were developed ad hoc, although some of the indicators were extrapolated from previous studies about motivation.

Alongside with questions on the demographic profile (age, sex, nationality and the level of previous experience), the final questionnaire contains 23 indicators (Table 2) that encompass the various levels of the volunteer experience mentioned in our conceptual framework: altruism-spirituality (three indicators on ethical behaviour, religious motivations); social—social value (eight indicators on meeting other people, forming relationships, making friends); hedonism (six indicators on play, amusement); functional-efficiency (four indicators on doing useful things, being useful for other people); and sacrifice (two items on time and effort costs incurred). All indicators conforming the questionnaire, with verbs expressed in future for the first survey (pre-event) and in past for the second survey (post-event), were expressed on a 5-point Likert scale positively, except the cost dimension.

\section{Respondents Description: The Event and the Volunteers}

The mega event chosen for our empirical study was 5th World Meeting of Families, held in Valencia (Spain) chaired by the Pope Benedict XVI, which accounted for about 1,500,000 of pilgrims, from more than 87 different countries. Due to the 
Table 2 Indicators of volunteer experience used in the questionnaire

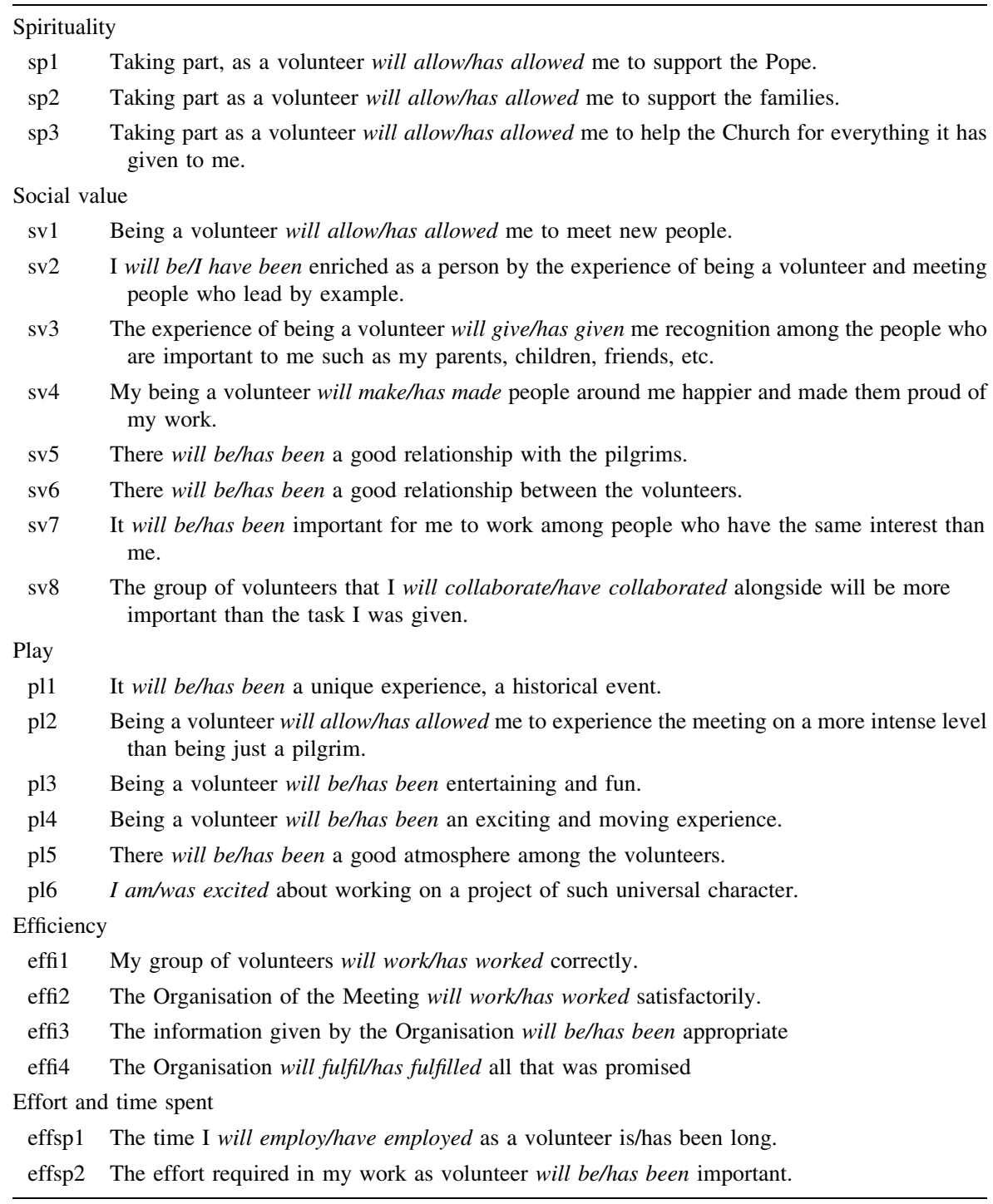

crowded participation, the Meeting needed a volunteering collaboration with an exceptional size to develop all planned activities. The organisation of more than 11,000 volunteers was set up as a pyramidal structure with different teams in the different areas of work. Each team had 15 or 20 volunteers and one team leader. The proposed functions for the different volunteers' teams were: 1. Attention; to pilgrims 2. administration and management, 3. Events' logistics; 4. Protocol; 5. Volunteer's logistics; 6. Control and Security and 7. Medical services.

The final questionnaire was sent in two waves via e-mail to 9,199 volunteers out of a total of 11,000 in the organisation database who provided an e-mail address 
Table 3 Sample profile

\begin{tabular}{|c|c|c|}
\hline \multicolumn{3}{|l|}{ Sex } \\
\hline Men & 304 & $42.76 \%$ \\
\hline Women & 407 & $57.24 \%$ \\
\hline \multicolumn{3}{|l|}{ Nationality } \\
\hline Valencia & 450 & $63.29 \%$ \\
\hline Alicante & 40 & $5.63 \%$ \\
\hline Castellón & 25 & $3.52 \%$ \\
\hline Other from Spain & 158 & $22.22 \%$ \\
\hline Foreigners & 38 & $5.34 \%$ \\
\hline \multicolumn{3}{|c|}{ Previous experience as volunteer } \\
\hline Never & 455 & $63.99 \%$ \\
\hline Once & 60 & $8.44 \%$ \\
\hline Several & 196 & $27.57 \%$ \\
\hline \multicolumn{3}{|l|}{ Age } \\
\hline From 16 to 25 & 298 & $41.91 \%$ \\
\hline From 26 to 35 & 215 & $30.24 \%$ \\
\hline From 36 to 50 & 140 & $19.69 \%$ \\
\hline More than 50 & 58 & $8.16 \%$ \\
\hline
\end{tabular}

(convenience sample). We obtained 1,330 useable responses in the pre-event wave (3 months before) and 1,638 in the post-event wave (1 month after it finished). After tracking respondents with the volunteer code, 711 volunteers were found to have responded twice (which gave a $7.7 \%$ response rate).

The profile of the volunteers in the sample (Table 3 ) is mainly young people (72\% under 36) and slightly more females (57\%), Spanish (95\%) and mostly from the city of Valencia (63\%). It is also important to note that $64 \%$ of the volunteers had no previous experience of this type of activity (due to the low percentage of volunteers in the sample ( $8 \%$ ) who had little experience of volunteering, this group was added to the volunteers with no experience in order to simplify interpretation of the results).

\section{Analysis and Findings}

Pre-analysis: Scales' Reliability and Validity

As a previous step before building the index, the scales' psychometric properties were tested (reliability and discriminant and convergent validity). In Table 4, first column shows the coefficient alpha for all constructs, exceeding 0.70 (Nunnally 1978). Composite reliability, a more accurate measure that does not assume equal item weighting (tau equivalency), is even higher (the minimum value is 0.84 for Social Value in the pre-assessment structure).

It is recommended (Fornell and Larcker 1981) that the average variance extracted (AVE) should be greater than 0.5 (square root bigger than 0.71 ), which in our case it is true neither for social value in both assessments, nor for play in the 
Table 4 Intercorrelations and internal consistencies of constructs for the pre-assessment and postassessment structure

\begin{tabular}{lllllll}
\hline Alpha & $\begin{array}{l}\text { Composite } \\
\text { reliability }\end{array}$ & sp & sv & pl & effi & effsp \\
\hline
\end{tabular}

Pre-assessment

$\begin{array}{llllllll}0.78 & 0.87 & \text { sp } & \mathbf{0 . 8 4} & & & & \\ 0.78 & 0.84 & \text { sv } & 0.25 & \mathbf{0 . 6 3} & & & \\ 0.78 & 0.85 & \text { pl } & 0.21 & 0.70 & \mathbf{0 . 6 9} & & \\ 0.82 & 0.88 & \text { effi } & 0.23 & 0.46 & 0.51 & \mathbf{0 . 8 1} & \\ 0.85 & 0.93 & \text { effsp } & 0.11 & 0.20 & 0.18 & 0.14 & \mathbf{0 . 9 3}\end{array}$

Post-assessment

\begin{tabular}{lllllllll}
0.86 & 0.92 & sp & $\mathbf{0 . 8 9}$ & & & & \\
0.80 & 0.85 & sv & 0.51 & $\mathbf{0 . 6 5}$ & & & \\
0.81 & 0.86 & pl & 0.48 & 0.75 & $\mathbf{0 . 7 2}$ & & \\
0.86 & 0.90 & effi & 0.38 & 0.47 & 0.52 & $\mathbf{0 . 8 4}$ & \\
0.85 & 0.93 & effsp & 0.29 & 0.31 & 0.26 & 0.08 & $\mathbf{0 . 9 3}$ \\
\hline
\end{tabular}

The bold numbers on the diagonal are the square root of the variance shared between the constructs and their measures

$S p$ spirituality, $s v$ social value, $p l$ play, effi efficiency, effsp effort and time spent

pre-assessment structure. Fornell and Larcker (1981) also suggested that as a mean of evaluating discriminant validity, the square roots of the AVEs of the constructs should be greater than the correlations among the constructs. In our case this only fails for the correlation among play and social value, in both stages.

Table 5 provides the correlations of each item to its intended construct (loadings) and to all other constructs (cross loadings). Although there is some cross-loading, all items load more highly on their own construct. This is true for both stages.

Methodological Procedure for Building the Index

In order to globally assess the perceived value of the experience and categorise volunteers based on socio-demographic variables, we built a global index for the sample of the 711 volunteers who responded to both surveys (before and after the event). The index was created especially to describe the self-assessment of the volunteers using the system proposed by Guinot et al. (2001). The method, called multi-table analysis, consists of building a structural model in which data are grouped into blocks of indicators, with the indicators in each block being interrelated so that each block is essentially one-dimensional. The structural model creates a latent variable for each block and unites all the blocks, with the block resulting from the concatenation of all the blocks.

In this case the data were arranged in five blocks, in line with the dimensionality of the proposed value model: 'spirituality', 'social value', 'play', 'efficiency' and 'effort'. Figure 1 shows the diagram of the proposed structural model for building the index. 
Table 5 Item-to-scale correlation (pre and post experience)

\begin{tabular}{lrlllllllllll}
\hline Pre & \multicolumn{1}{l}{ sp } & sv & pl & effi & effsp & Post & sp & sv & pl & effi & effsp \\
\hline sp1 & $\mathbf{0 . 8 1}$ & 0.19 & 0.19 & 0.20 & 0.14 & sp1 & $\mathbf{0 . 9 2}$ & 0.44 & 0.42 & 0.36 & 0.27 \\
sp2 & $\mathbf{0 . 8 6}$ & 0.30 & 0.25 & 0.23 & 0.08 & sp2 & $\mathbf{0 . 8 8}$ & 0.49 & 0.48 & 0.32 & 0.29 \\
sp3 & $\mathbf{0 . 8 4}$ & 0.13 & 0.09 & 0.14 & 0.06 & sp3 & $\mathbf{0 . 8 6}$ & 0.42 & 0.38 & 0.35 & 0.23 \\
sv1 & -0.00 & $\mathbf{0 . 6 6}$ & 0.51 & 0.24 & 0.11 & sv1 & 0.26 & $\mathbf{0 . 7 2}$ & 0.53 & 0.27 & 0.27 \\
sv2 & 0.21 & $\mathbf{0 . 7 0}$ & 0.51 & 0.33 & 0.12 & sv2 & 0.44 & $\mathbf{0 . 7 5}$ & 0.59 & 0.36 & 0.24 \\
sv3 & 0.08 & $\mathbf{0 . 5 8}$ & 0.32 & 0.17 & 0.18 & sv3 & 0.18 & $\mathbf{0 . 5 7}$ & 0.33 & 0.18 & 0.20 \\
sv4 & 0.12 & $\mathbf{0 . 6 2}$ & 0.35 & 0.16 & 0.15 & sv4 & 0.28 & $\mathbf{0 . 6 4}$ & 0.40 & 0.22 & 0.25 \\
sv5 & 0.24 & $\mathbf{0 . 6 7}$ & 0.45 & 0.43 & 0.09 & sv5 & 0.40 & $\mathbf{0 . 5 7}$ & 0.44 & 0.38 & 0.07 \\
sv6 & 0.22 & $\mathbf{0 . 7 0}$ & 0.50 & 0.46 & 0.08 & sv6 & 0.39 & $\mathbf{0 . 6 3}$ & 0.57 & 0.42 & 0.12 \\
sv7 & 0.30 & $\mathbf{0 . 6 5}$ & 0.52 & 0.34 & 0.14 & sv7 & 0.48 & $\mathbf{0 . 7 2}$ & 0.57 & 0.36 & 0.21 \\
sv8 & 0.05 & $\mathbf{0 . 4 4}$ & 0.33 & 0.14 & 0.16 & sv8 & 0.17 & $\mathbf{0 . 5 5}$ & 0.41 & 0.20 & 0.19 \\
p11 & 0.32 & 0.36 & $\mathbf{0 . 6 1}$ & 0.31 & 0.16 & pl1 & 0.40 & 0.50 & $\mathbf{0 . 6 9}$ & 0.33 & 0.21 \\
p12 & 0.17 & 0.35 & $\mathbf{0 . 6 1}$ & 0.26 & 0.18 & p12 & 0.27 & 0.44 & $\mathbf{0 . 6 6}$ & 0.30 & 0.16 \\
p13 & -0.09 & 0.49 & $\mathbf{0 . 7 1}$ & 0.29 & 0.07 & p13 & 0.25 & 0.53 & $\mathbf{0 . 7 2}$ & 0.33 & 0.19 \\
p14 & 0.10 & 0.56 & $\mathbf{0 . 7 9}$ & 0.38 & 0.16 & p14 & 0.39 & 0.62 & $\mathbf{0 . 8 3}$ & 0.40 & 0.28 \\
p15 & 0.16 & 0.63 & $\mathbf{0 . 7 2}$ & 0.52 & 0.11 & p15 & 0.38 & 0.58 & $\mathbf{0 . 6 5}$ & 0.51 & 0.12 \\
p16 & 0.25 & 0.48 & $\mathbf{0 . 7 1}$ & 0.36 & 0.08 & pl6 & 0.39 & 0.55 & $\mathbf{0 . 7 4}$ & 0.37 & 0.15 \\
effi1 & 0.16 & 0.41 & 0.45 & $\mathbf{0 . 7 6}$ & 0.07 & effi1 & 0.35 & 0.48 & 0.52 & $\mathbf{0 . 6 8}$ & 0.18 \\
effi2 & 0.25 & 0.41 & 0.44 & $\mathbf{0 . 9 0}$ & 0.13 & effi2 & 0.33 & 0.37 & 0.43 & $\mathbf{0 . 8 8}$ & 0.03 \\
effi3 & 0.21 & 0.33 & 0.37 & $\mathbf{0 . 8 6}$ & 0.12 & effi3 & 0.28 & 0.36 & 0.38 & $\mathbf{0 . 8 8}$ & 0.04 \\
effi4 & 0.08 & 0.36 & 0.38 & $\mathbf{0 . 7 0}$ & 0.14 & effi4 & 0.34 & 0.38 & 0.43 & $\mathbf{0 . 9 0}$ & 0.04 \\
effsp1 & 0.09 & 0.175 & 0.175 & 0.13 & $\mathbf{0 . 9 3}$ & effsp1 & 0.25 & 0.28 & 0.24 & 0.06 & $\mathbf{0 . 9 3}$ \\
effsp2 & 0.10 & 0.193 & 0.159 & 0.13 & $\mathbf{0 . 9 3}$ & effsp2 & 0.29 & 0.29 & 0.25 & 0.09 & $\mathbf{0 . 9 3}$ \\
\hline Bol & & & & & & & & \\
sin
\end{tabular}

Bold values indicate items that load on their own construct $s p$ spirituality, $s v$ social value, $p l$ play, effi efficiency, effsp effort and time spent

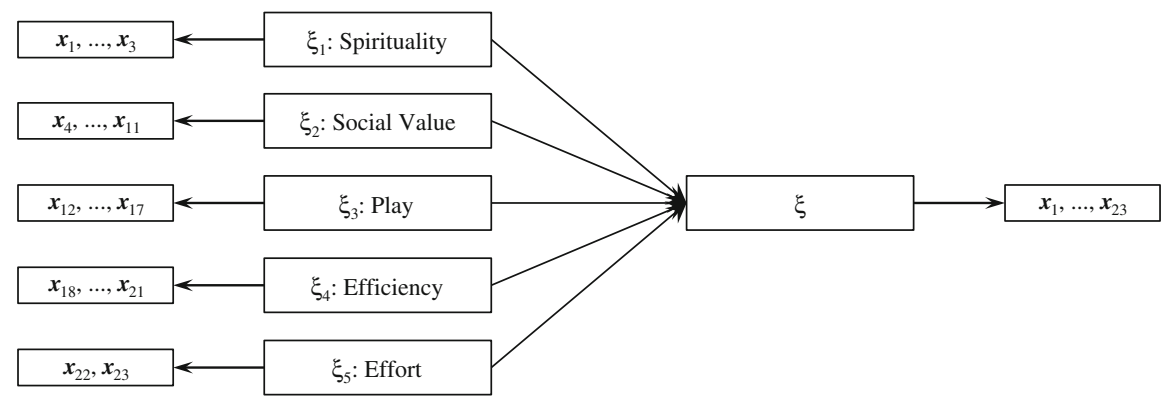

Fig. 1 Structural model for multi-table analysis

The index (its explicit expression based on the indicators) was obtained by estimating the above model. To do this we used MBPLSPM or Multiblock PLS path modelling (Arteaga et al. 2010) which provided the weight of the indicators in the 
construction of the index. To make the index easier to read, it was normalised to mean 0 and variance 1 .

The weights obtained enabled us to extract the normalised value of the index based on the original responses to the 23 questions.

The index was built based on the volunteer's assessment of their experience of the event both before and after it took place. Hence the index is designed to be an objective measure of the value of the experience, which in some way is measured using the 23 indicators at two different points in time. The higher the index, the higher (in terms of the degree of agreement) are the volunteers' assessments of their expectations and subsequent perceptions of the value of the experience.

\section{Measuring Significant Differences on the Value Index Through ANOVAs}

As a further step, in order to give answer to the sub-objectives named in the introduction we used analysis of variance (ANOVA) to examine which factors (age, sex and experience) have a significant effect on the average index value. The LeastSignificant Differences (LSD) intervals were represented to show what any significant differences we found consisted of.

Then, the index obtained for each of the volunteers was used to sort them from the lowest to highest to give a range of indices, where position 711 was the volunteer who had the highest value for the index and position 1 was the volunteer with the lowest value for it. These data were then used to examine whether there were any differences in it due to the volunteer's profile and the two different points in time.

The results of the variance analysis are shown in Table 6. It can be seen that in the pre-event assessment results there was a significant age $(p=0.00)$ and sex $(p=0.01)$ factor effect on the average index value. The reverse occurs in the case with the post-event assessment results, as only the previous experience factor had a significant effect $(p=0.01)$ on the average index value, although the age factor was close to having one $(p=0.08)$.

ANOVA indicates the factors that had a significant effect on the average index value but not what any differences consisted of. To understand these differences we used the LSD intervals shown in Fig. 2. In these intervals the existence of a significant difference between two means is reflected in that its corresponding intervals do not overlap.

Figure 2 shows that the average index value before the event (i.e. the value of the experience based on expectations) of volunteers under 25 was significantly higher

Table 6 ANOVA for the mean of the index, in function of the age, the sex and the previous experience

\begin{tabular}{|c|c|c|c|c|c|c|c|c|c|}
\hline \multicolumn{5}{|c|}{ Before the event } & \multicolumn{5}{|c|}{ After the event } \\
\hline Source & SS & df & MS & $p$-value & Source & SS & df & MS & $p$-value \\
\hline Age & 19.81 & 3 & 6.60 & $<0.01$ & Age & 6.59 & 3 & 2.20 & $>0.05$ \\
\hline Sex & 7.57 & 1 & 7.57 & $<0.01$ & Sex & 1.78 & 1 & 1.78 & $>0.05$ \\
\hline Exp & 1.32 & 1 & 1.32 & $>0.05$ & Exp & 6.94 & 1 & 6.94 & $<0.01$ \\
\hline Error & 679.38 & 705 & 0.96 & & Error & 692.24 & 705 & 0.98 & \\
\hline Total & 708.09 & 710 & & & Total & 707.56 & 710 & & \\
\hline
\end{tabular}


Evaluation before the event
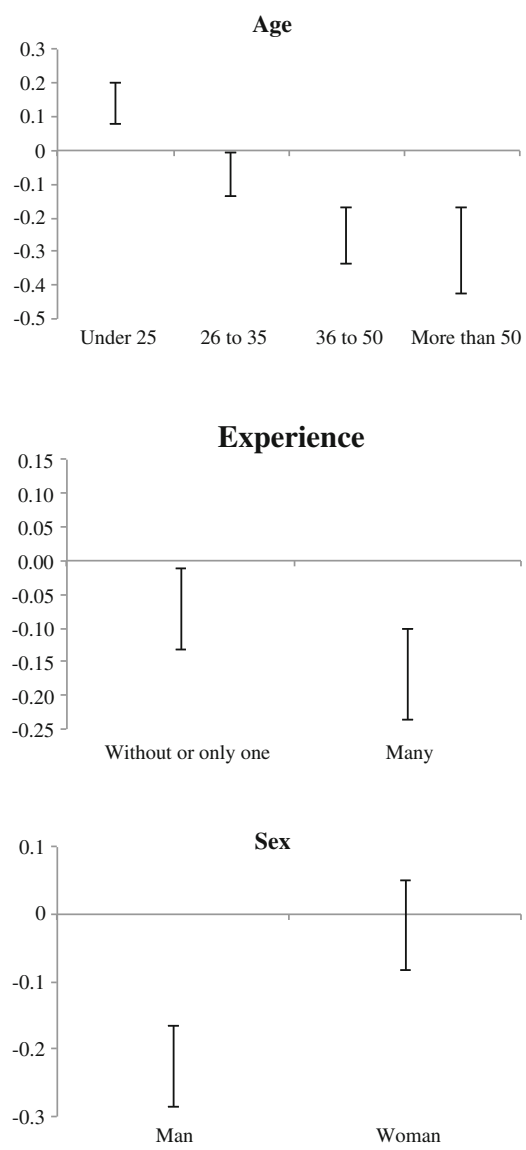

Evaluation after the event

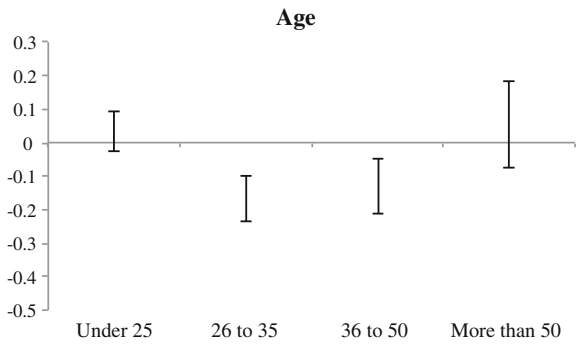

\section{Experience}
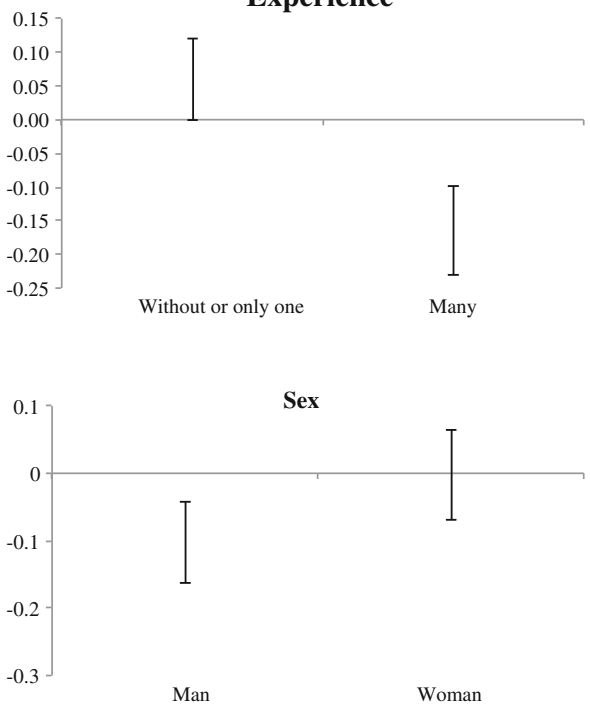

Fig. 2 LSD intervals to explain the mean differences found in the ANOVA analysis

than for the 26-35 age group which, in turn, was higher than that for the other groups. However, there were no significant differences (overlaps in Fig. 2) related to age in the index after the event. (i.e. the value of the experience based on the actual perceptions).

As regards having or not previous experience as a volunteer, the average index value does not show any significant differences in terms of expectations (i.e. before the event). However, there are some for actual perceptions (i.e. after the event) as the group with less experience has a significantly higher average index value.

Finally, with respect to sex, the average index value for expectations in the preevent assessment showed significant differences between men and women, with the former having a lower average value for their expectations as a volunteer at this event. By contrast, no significant differences were found by sex in the post-volunteer experience assessment. 


\section{Ranking of the Index on Three Factors (Sex, Age and Previous Experience)}

To supplement the analysis, once the profile of the volunteers had been described (Table 3), the average rates calculated (Fig. 1; Table 6) and the significance of the differences analysed (Fig. 2), we offer further analysis on the ranking of the index based upon the three socio-demographic variables (Table 7; Fig. 3). In Fig. 3 we represent the average for the index, grouping by age, sex and previous experience. The aim is comparing the position of each group, sorting by the mean of the index, in the pre and the post experience. Table 7 shows these averages, but sorted by the average value of the index (position) so that the first position is occupied by the group whose average index value is greater. Thus, having positions in the two

Table 7 Average values for the index, grouping by age, sex and previous experience, and number of positions changed from the pre to the post experience

\begin{tabular}{|c|c|c|c|c|c|c|}
\hline & \multicolumn{2}{|l|}{ Before } & \multicolumn{2}{|l|}{ After } & \multicolumn{2}{|c|}{ Positions changed } \\
\hline & Index & Position & Index & Position & & \\
\hline Up to 25 ; man; with exp. & 0.15 & 4 & 0.10 & 5 & $\downarrow$ & 1 \\
\hline Up to 25 ; man; without exp. & 0.09 & 5 & 0.03 & 6 & $\downarrow$ & 1 \\
\hline Up to 25 ; woman; with exp. & 0.30 & 1 & -0.08 & 10 & $\downarrow$ & 9 \\
\hline Up to 25 ; woman; without exp. & 0.23 & 2 & 0.19 & 3 & $\boldsymbol{v}$ & 1 \\
\hline 26-35; man; with exp. & -0.37 & 13 & -0.41 & 15 & $\downarrow$ & 2 \\
\hline 26-35; man; without exp. & -0.15 & 10 & -0.13 & 11 & $\downarrow$ & 1 \\
\hline 26-35; woman; with exp. & -0.14 & 9 & -0.43 & 16 & $\downarrow$ & 7 \\
\hline 26-35; woman; without exp. & 0.22 & 3 & 0.14 & 4 & $\downarrow$ & 1 \\
\hline 36-50; man; with exp. & -0.12 & 8 & -0.19 & 12 & $\downarrow$ & 4 \\
\hline 36-50; man; without exp. & -0.42 & 14 & -0.01 & 7 & $\uparrow$ & 7 \\
\hline 36-50; woman; with exp. & -0.50 & 15 & -0.23 & 13 & $\uparrow$ & 2 \\
\hline 36-50; woman; without exp. & -0.01 & 6 & -0.03 & 9 & $\downarrow$ & 3 \\
\hline More than 50; man; with exp. & -0.25 & 12 & -0.34 & 14 & $\downarrow$ & 2 \\
\hline More than 50; man; without exp. & -0.52 & 16 & -0.02 & 8 & $\uparrow$ & 8 \\
\hline More than 50; woman; with exp. & -0.24 & 11 & 0.39 & 1 & $\uparrow$ & 10 \\
\hline More than 50; woman; without exp. & -0.06 & 7 & 0.23 & 2 & $\uparrow$ & 5 \\
\hline
\end{tabular}




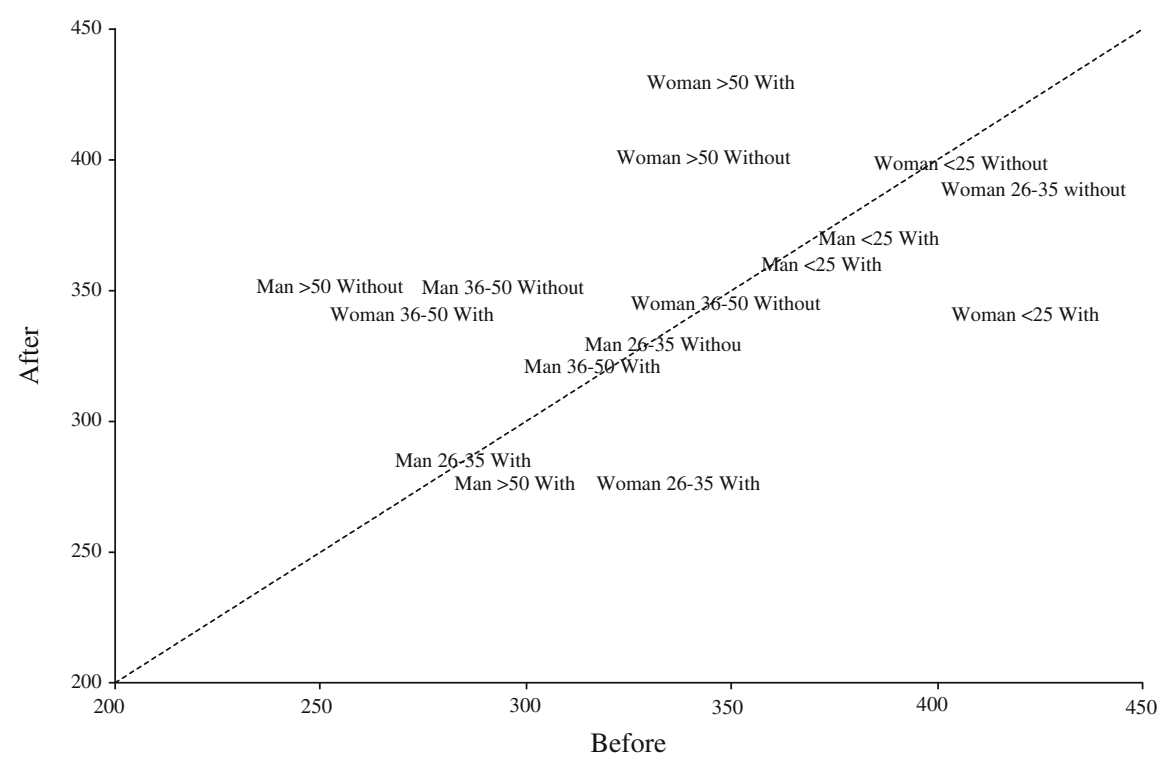

Fig. 3 Ranking before and after the event, grouped by gender (man, woman), age $(<25,26-35,36-50$, $>50$ ) and experience (without, with)

moments, the last column indicates explicitly the number of positions gained or lost each group.

Table 7 provides, in a first level, information on differences by sex, previous experience and age. In relation to the analysis of the mean value of the index by sex, in general and without considering age and previous experience, the average results for women had a higher position in the total value of the volunteer experience (the three first positions in both assessments are occupied by groups of women).

In terms of previous experience or not as a volunteer, the volunteers with experience (with the exception of the two groups of elderly women) on average had higher positions in the pre-event assessment than in the post-event assessment.

As regards the analysis by age, the top positions in the pre-event are occupied by youth, and in the post-event are occupied by the elderly.

In a second level, Table 7 also provides detailed information on the results taking into account the comparison of different groups in the pre and post experience (column changed positions).

First, only volunteers over 35 years (groups 36-50 and especially the group of $>50$ ) improved their perception of the event upon completion. Group 'women over 50 years, with experience', move from position 11 of 16 (very poor expectations) to the first position (the highest value for the experience); they improved ten positions. Group 'men over 50 years with no experience', changed from the last position (very low expectations) to eighth position (more satisfied than they expected); they improved eight positions. Perhaps these results are due to the fact that the older group on average appeared to have more realistic value expectations about the volunteering experience. Nevertheless, it could also be because the volunteer work 
was more self-rewarding for the older volunteers. Future research in this area will help to come to more exact conclusions.

Second, a clearly negative change expectations-results in terms of age can be appreciated; the younger volunteers (aged under 25 and in the interval from 25 to 36) occupy the first positions in the pre-event assessment than for the post-event one. In particular, group 'younger women experienced' moving from the first position in the pre-event (very high expectations) to the 10th position in the postevent (disappointment with the result), worsen nine positions. Something similar happens with group 'women 26-35 experienced', worsening seven positions.

Furthermore, Fig. 3 graphically shows the averages for the index, in order to provide a more intuitive understanding. The groups that on average had similar positions in their pre- and post-event assessments are located around the diagonal. The groups that on average had more advanced positions in their assessments after the event are above the diagonal, while the groups, which had high expectations that were lowered in the later assessment, are below it.

Changes in the groups far from the diagonal are significant. The groups of men and women aged over 50 were on average in more advanced positions in their assessments after the event, but there were sex differences in this age group as on average the group of women aged over 50 were in more advanced positions in both their pre-event and post-event assessments.

The two groups of women with experience aged under 35 are below the diagonal and hence their assessment of the experience after the event was lower on average. However, the youngest ( $<25$ years) had a very high average pre-event assessment.

\section{Conclusions and Managerial Implications}

From a theoretical view we have enhanced our understanding of volunteer behaviour in tourism events, adopting a value-based approach that is somewhat unusual in the research of volunteering.

In this paper we have built an index of perceived value as an objective measure of the self-assessment of volunteers' experience at a religious mega event. We have also analysed this index at two different points in time: before the event, i.e. measuring expectations of value, and after the event, in other words the outcome. This index was built using a specific methodology that allows having a final unique measure as a compendium of the scores and weights presented by respondents asked about five dimensions of their experience: efficiency, spirituality, social value, play and effort.

The results obtained show that in terms of the volunteers' expectations of the event, young people and women were much more enthusiastic in the pre-experience assessment, while the older age groups and men and in general volunteers with experience had a lower average index.

Furthermore, no sex or age differences were observed between the groups when examining the results of the post-event assessment of the experience, although people aged over 50 were more positive when evaluating it. By contrast, significant differences were observed in the group of volunteers with little or no experience, as 
this group rated having been a volunteer at this event much more positively than the group with extensive experience in volunteerism.

As a possible further analysis of the before-and-after effect, influence of age, sex and prior experience could be assessed on each value dimension in both moments. Our focus has been on the index as an aggregate measure; the significance of these differences for each value dimension between the pre- and post-event assessment has not been tested, which we note as a limitation of this paper. This sort of longitudinal studies are of interest for the motivation and training of volunteers and may indicate differences for each socio-demographic variable and for each of the dimensions, which is proposed as a future line of research. An extra limitation of this work is that no differences have been tested according to the nationality of the respondents. As cultural differences, in the understanding of what volunteering is, have been signalled in our conceptual framework, testing differences between Spanish and foreign volunteers may though be light, adding knowledge on one of the major reasons underlying the statistical differences of Spain, within other Western countries.

In terms of managerial implications, the idea of assessing before and after the activity and also classifying volunteers may help event organisers. Our study stresses the importance of measuring volunteers' expectations, as for several sociodemographic groups, sharp differences has been noticed between both moments. In this sense, volunteers cannot be seen as just a source of unpaid labour; event managers need to build an understanding of the factors which help to ensure that volunteers carry out their tasks successfully. Proper assessment not only of their motives, as is usually carried out, but also of their expectations can help to understand the rewarding nature of this kind of experience and thus achieve enhanced performance by this quiet force in event organisation. If these unpaid workers are essential to the smooth running of events, these must somehow generate opportunities to satisfy volunteers' functional and emotional needs. Much has to be gained out of this deal in accordance with their loyalty to the organisation: both the repeat behaviour (being involved again, when dealing with episodic volunteers) and the recommendation (bringing new volunteers as result of a positive word-of-mouth communications about the experience) are both main objectives that the organisation involved with volunteers should seek.

Furthermore, according to the results on young volunteers, and because of the idiosyncrasy of episodic volunteer, there is a chance to adopt a network-based strategy, which has already been recognised as being valuable when organising and hosting events (McGehee and Santos 2005). Involving volunteers in networks both during and after an event is important to successfully follow-up and retain them.

\section{References}

Arteaga, F., Gallarza, M. G., \& Gil, I. (2010). A new multiblock PLS based method to estimate causal models. Application to the post-consumption behavior in tourism. In E. Vinci, W. W. Chin, J. Henseler, \& H. Wang (Eds.), Handbook of partial least squares: Concepts, methods and applications in marketing and related fields. Handbook of computational statistics. Berlin: Springer. 
Beerly, A., Diaz, G., \& Martin, J. (2004). The behavioural consequences of self-congruency in volunteers. International Journal of Nonprofit and Voluntary Sector Marketing, 9(1), 28-48.

Berry, L. L., \& Yadav, M. S. (1997). El papel del valor en la determinación del precio de los servicios. Harvard Deusto Business Review, 78, 26-37.

Callow, M. (2004). Identifying promotional appeals for targeting potential volunteers: an exploratory study on volunteering motives among retirees. International Journal of Nonprofit and Voluntary Sector Marketing, 9(3), 261-270.

Charities Aid Foundation. (2011). World Giving Index 2011. Retrieved from https://www.cafonline.org/ pdf/world_giving_index_2011_191211.pdf.

Cnaan, R. A., Handy, F., \& Wadsworth, M. (1996). Defining who is a volunteer: Conceptual and empirical considerations. Nonprofit and Voluntary Sector Quarterly, 25(3), 364-383.

GHK Consulting. (2010). Volunteering in the European Union. Educational, Audiovisual \& Culture Executive Agency (EAC-EA). Directorate General Education and Culture (DG EAC).

Crompton, J. L., \& McKay, S. L. (1997). Motives of visitors attending festival events. Annals of Tourism Research, 24(2), 425-439.

Cuskelly, G., Auld, C., Harrington, M., \& Coleman, D. (2004). Predicting the behavioural dependability of sport event volunteers. Event Management, 9, 73-89.

Dávila, M. C., \& Chacón, F. (2004). Variables sociodemográficas y permanencia de diferentes tipos de voluntariado. Papeles del Psicólogo, 25(89), 44-57.

Dávila, M. C., Vecina, M. L., \& Chacón, F. (2005). Análisis de las tasas de abandono en una muestra de voluntarios y causas más frecuentes. Psicología ambiental, comunitaria y de la educación, 5, 205-212.

Day, E., \& Crask, M. R. (2000). Value assessment: The antecedent of customer satisfaction. Journal of Consumer Satisfaction, Dissatisfaction and Complaining Behavior, 13, 42-50.

Elstad, B. (1996). Volunteer perception of learning and satisfaction in a mega-event: The case of the Olympic winter games in Lillehammer. Festival Management and Event Tourism, 4, 75-83.

Elstad, B. (2003). Continuance commitment and reasons to quit: A study of volunteers at a jazz festival. Event Management, 8(2), 99-108.

Farrell, J., Johnston, M., \& Twynam, D. (1998). Volunteer motivation, satisfaction, and management at an elite sporting competition. Journal of Sport Management, 12, 288-300.

Fayos-Solá, E. (1997). The impact of mega events. Annals of Tourism Research, Research Notes and Reports, 25(1), 241-244.

FOLIA (Franco \& Guillo). (2011). Diagnóstico de la situación del voluntariado de acción social en España. Estudio y sistema de indicadores clave. Observatorio del voluntariado PVE, Plataforma del Voluntariado de España, Madrid.

Fornell, C., \& Larcker, D. F. (1981). Evaluating structural equation models with unobserved variables and measurement errors. Journal of Marketing Research, XVIII, 39-50.

Gallarza, M. G. (2000). Voluntary sector. In J. Jafari (Ed.), Encyclopedia of tourism (pp. 622-623). London: Routledge.

Gallarza, M. G., \& Gil, I. (2006). Value dimensions, perceived value, satisfaction and loyalty: an investigation of university students' travel behaviour. Tourism Management, 27(3), 437-452.

Gallarza, M. G., \& Gil, I. (2008). The Concept of Value and its dimensions. A tool for analysing tourism experiences. Tourism Review, 63(3), 4-20.

Gallarza, M. G., Gil-Saura, I., \& Holbrook, M. B. (2011). The value of value: Further excursions on the meaning and role of customer value. Journal of Consumer Behaviour, 10(4), 179-191.

García, R., Morales, V., Hernández, A., \& Chica, E. (2011). Una herramienta para evaluar la calidad y la permanencia en el voluntariado deportivo. Cuadernos de psicología del deporte, 11(2), 171-178.

García-Mainar, I., \& Marcuello, C. (2007). Members, volunteers and donors in nonprofit organizations in Spain. Nonprofit and Voluntary Sector Quarterly, 36, 100-120.

Garrido, M. (2011). El voluntariado en España: Identidad, funciones y retos para su fortalecimiento. Revista Española del Tercer Sector, 18 May-Ago.

Getz, D. (1997). Event management and event tourism. New York, NY: Cognizant Communication Corporation.

Goeldner, R. C., Ritchie, J. R. B., \& McIntosh, W. R. (2000). Tourism. Principles, practices, philosophies. New York, NY: Wiley.

Guinot, C., Latreille, J., \& Tenenhaus, M. (2001). PLS path modelling and multiple table analysis. Application to the cosmetics habits of women in Ile-de-France. Chemometrics and Intelligent Laboratory Systems, 36, 247-259. 
Gursoy, D., \& Kendall, K. W. (2006). Hosting mega events modelling locals' support. Annals of Tourism Research, 33(3), 603-623.

Handy, F., Bradeur, N., \& Cnaan, R. A. (2006). Summer in the island: Episodic volunteering. Voluntary Action, 7(3), 31-46.

Handy, F., Cnaan, R. A., Bradney, J. L., Acoli, U., Meijs, L. C. M. P., \& Ranade, S. (2000). Public perception of "who is a volunteer": An examination of the net-cost approach form a cross-cultural perspective. VOLUNTAS: International Journal of Voluntary and Nonprofit Organizations, 11(1), 45-65.

Heskett, J. L., Sasser, W. E., \& Schlesinger, L. A. (1997). The service profit chain. How leading companies link profit and growth to loyalty, satisfaction, and value. New York, NY: The Free Press.

Hibbert, S., Piacentini, M., \& Al Dajani, H. (2003). Understanding volunteer motivation for participation in a community-based food cooperative. International Journal of Nonprofit and Voluntary Sector Marketing, 8(1), 30-42.

Holbrook, M. B. (1999). Consumer value. A framework for analysis and research. London: Routledge.

Holbrook, M. B., \& Corfman, K. P. (1985). Quality and value in the consumption experience: Phaedrus rides again. In J. Jacoby \& J. C. Olson (Eds.), Perceived quality: How consumers view stores and merchandise (pp. 31-57). Lexington, MA: D.C. Health and Company.

Holbrook, M. B., \& Hirschman, E. C. (1982). The experiential aspects of consumption: Consumer fantasies, feelings and fun. Journal of Consumer Research, 9, 132-140.

Holmes, K., Smith, K. A., Lockestone-Binney, L., \& Baum, T. (2010). Developing the dimensions of tourism volunteering. Leisure Sciences, 32, 255-269.

Jensen, H. R. (1996). The interrelationship between customer and consumer value. Asia Pacific Advances in Consumer Research, 2, 60-63.

Kemp, S. (2002). The hidden workforce: volunteers' learning in the Olympics. Journal of European Industrial Training, 26(2-4), 109-116.

Kim, H. J., Gursoy, D., \& Lee, S. (2006). The Impact of the 2002 World Cup on South Korea: Comparisons of pre- and post-games. Tourism Management, 27, 86-96.

Kim, S. S., \& Morrison, A. M. (2005). Change of images of South Korea among foreign tourists after the 2002 FIFA World Cup. Tourism Management, 26, 233-247.

Kotler, P., Keller, P., Brady, M., Goodman, M., \& Hensen, T. (2009). Marketing Management. Harlow: Prentice Hall.

Lee, C., Lee, Y., \& Lee, B. (2006). Korea's destination image formed by the 2002 World Cup. Annals of Tourism Research, 32(4), 839-858.

Lee, C., \& Taylor, T. (2005). Critical reflections on the economic impact assessment of a mega-event: the case of 2002 FIFA World Cup. Tourism Management, 26, 595-603.

Lovelock, C. H. (1996). Services Marketing (3rd ed.). Upper Saddle River, NJ: Prentice Hall.

McCurley, S. H., and Vesuvio, D. (1985). Brief response: Who is a volunteer. Voluntary Action Leadership, Summer, 14-15.

McGehee, N. G., \& Santos, C. A. (2005). Social change, discourse and volunteer tourism. Annals of Tourism Research, 32(3), 760-779.

Mellor, D., Hayashi, Y., Stokes, M., Firth, L., Lake, L., Staples, M., et al. (2009). Volunteering and its relationship with personal and neighbourhood well-being. Nonprofit and Voluntary Sector Quarterly, 38(1), 144-159.

Monga, M. (2006). Measuring motivation to volunteer for special events. Event Management, 10(1), 47-61.

Monroe, K. B. (2003). Pricing: Making profitable decisions (3rd ed.). New York, NY: McGraw-Hill/ Irwin.

Nilson, T. H. (1992). Value-added marketing: Marketing management for superior results. Berkshire: McGraw Hill.

Nunnally, J. C. (1978). Psychometric theory (2nd ed.). New York, NY: McGraw Hill.

Plataforma de Promoción de Voluntariado de España. (2011). Diagnóstico de la situación del voluntariado de acción social en España. Madrid: Ministerio de Sanidad, Política Social e Igualdad.

Ritchie, J. (1984). Assessing the impact of hallmark events. Conceptual and research issues. Journal of Travel Research, 23, 2-11.

Ritchie, J. R. B., \& Aitken, C. (1984). Olympulse I: The research program and initial results. Journal of Travel Research, 22(1), 17-25.

Ruiz Olabuénaga, J. I. (2001). El voluntariado en España. Documentación Social, 122, 67-83. 
Saleh, F., \& Wood, C. (1998). Motives of volunteers in multicultural events; the case of Saskatoon Folkfest. Festival Management and Event Tourism, 5, 59-70.

Sheth, J. N., Newman, B. I., \& Gross, B. L. (1991). Why we buy what we buy: A theory of consumption values. Journal of Business Research, 22, 159-170.

Shonk, D. J., \& Chelladurai, P. (2008). Service quality, satisfaction, and intent to return in event sport tourism. Journal of Sport Management, 22(5), 587-602.

Smith, N. C. (1999). Ethics and the typology of customer value. In M. B. Holbrook (Ed.), Consumer value. A framework for analysis and research (pp. 147-158). London: Routledge.

Smith, K. A., Holmes, K., Haski-Leventhal, D., Cnaan, R. A., Handy, F., \& Brudney, J. L. (2010). Motivations and benefits of students volunteering: Comparing regular, occasional, and nonvolunteers in five countries. Canadian Journal of Nonprofit and Social Economy Research, 1(1), 65-81.

Strigas, A., \& Newton-Jackson, E. (2003). Motivating volunteers to serve and succeed: Design and results of a pilot study that explores demographics and motivational factors in sport volunteerism. International Sports Journal, 7(1), 111-123.

Sweeney, J., \& Soutar, G. (2001). Consumer perceived value: The development of a multiple item scale. Journal of Retailing, 77, 203-207.

Tao, H., \& Yeoh, P. (2007). Religion as an investment: Comparing the contributions and volunteer frequency among Christians, Buddhists, and folk religionists. Southern Economic Journal, 73(3), $770-790$.

Vaughan, L., \& Shiu, E. (2001). Multi-item scale to measure service quality within the voluntary sector. International Journal of Non Profit and Voluntary Sector Marketing, 6(2), 131-144.

Waitt, G. (2003). Social impacts of the Sydney Olympics. University of Wollongong, Australia. Annals of Tourism Research, 30(1), 194-215.

Weisbrod, B. A. (1975). Toward a theory of the voluntary non-profit sector in a three-sector economy (pp. 171-195). Madison, WI: Institute for Research on Poverty, University of Wisconsin.

Wilson, J. (2000). Volunteering. Annual Review of Sociology, 26, 215-240.

Woodruff, B. R. (1997). Customer value: The next source for competitive advantage. Journal of the Academy of Marketing Science, 25(2), 139-153.

Zeithaml, V. A. (1988). Consumer perceptions of price, quality, and value: A means-end model and synthesis of evidence. Journal of Marketing, 52, 2-22.

Zeithaml, V. A., \& Bitner, M. J. (1996). Services marketing. New York, NY: McGraw-Hill. 